\title{
AREA-WIDE MANAGEMENT OF Lobesia botrana IN MENDOZA, ARGENTINA
}

\author{
G. A. A. TARET, G. AZIN AND M. VANIN \\ Instituto de Sanidad y Calidad Agropecuaria de Mendoza (ISCAMEN) \\ Mendoza,Argentina; iscamen@iscamen.com.ar
}

\begin{abstract}
SUMMARY
The invasive European grapevine moth Lobesia botrana (Denis \& Schiffermüller) was first detected in 2010 in the Province of Mendoza, Argentina, after it became established in neighbouring Chile in 2008. Foreseeing the threat to the major wine and table grape industry of the Province of Mendoza, the Institute for Agricultural Sanitation and Quality of Mendoza Province (ISCAMEN), established the "Lobesia botrana Control and Eradication Programme" that has been following an area-wide integrated pest management (AW-IPM) strategy. The mainstay of this programme is widespread mating disruption against the adult moth population with judicious application of selective biological and chemical insecticides targeting the immature stages of the first two generations of the pest. We describe the spread of the pest in the Province of Mendoza since its introduction in 2010, the control tools currently being used, and the results achieved so far in suppressing the pest in the four main oases of Mendoza Province, as well as the future prospects for control. Before $L$. botrana detection, the absence of a major, direct pest of grapes meant that limited interventions were required in the management strategies used in the vineyards of the Province of Mendoza. Therefore, the challenge was to maintain a high level of natural biological control while introducing a pest management programme for $L$. botrana (i.e. mating disruption and conventional insecticides) that would not impact the complex of beneficial insects well established in the region. The situation required a great effort involving training, knowledge and technology transfer from public organizations to the private sector (growers and industry), and communication with environmental organizations. After two intensive control seasons with area-wide suppression of the pest as the main objective, population's levels of $L$. botrana have decreased dramatically. It required a substantial financial investment and technical effort to cover vineyards over a total area of 160000 ha. Decision making for suppression activities was supported by the use of mapping software (GIS) to visualize programme results every week in terms of moth population levels. Although the support from the industries and growers has been instrumental to the success of this area-wide programme, the challenge will be to maintain this support to further suppress the pest and, eventually in the future, to eradicate $L$. botrana from Mendoza Province.
\end{abstract}

Key Words: European grapevine moth, Tortricidae, invasive, integrated pest management, mating disruption, flowable pheromone, aerial sprays, immature stages, insect growth regulators, Bacillus thuringiensis kurstaki, Streptomyces avermitilis, grapes, wine industry 


\section{INTRODUCTION}

The European grapevine moth Lobesia botrana (Denis \& Schiffermüller) is a key pest of grapes (Vitis vinifera L.), that greatly impacts wine and table grape industries where it becomes established (Coscollá Ramón 1981, 1998; Zangheri et al. 1992; Armendáriz et al. 2007). It has been introduced to new regions as a result of trade and travel and is a serious threat for all the vine-growing areas that are presently unaffected (Ioriatti et al. 2012; CABI 2019). In 2010, this invasive moth was first detected in the Province of Mendoza, Argentina (SENASA 2015), close to the Chilean border. It became first established in Chile in 2008 (González 2008; SAG 2010) and spread rapidly to all grape growing regions of that country.

The favourable agroecological profile of Mendoza Province, and the absence of significant grape pests, allowed the development of a major wine and table grape industry, largely free of insecticide use. Production only involved occasional fungicide applications due to the favourable dry desert climate. Establishment of $L$. botrana would create significant changes to the existing pest management programme. Consequently, the Instituto de Sanidad y Calidad Agropecuaria de Mendoza (ISCAMEN) established on the $3^{\text {rd }}$ of March 2010 the "Lobesia botrana Control and Eradication Programme" to be implemented with the participation of producers and government organizations. It proposed an area-wide integrated pest management (AW-IPM) strategy based on the integration of mating disruption applied by ground and air against the adult moth population, and the application of selective biological and chemical insecticides directed at the immature stages of the first two generations of the pest.

Here we describe the introduction and spread of the pest in Mendoza Province, the control strategy and tools used with a focus on results achieved in 2017-2018, and prospects for control in future seasons.

\section{CHARACTERISTICS OF THE PEST AND DAMAGE}

The European grapevine moth is a multivoltine pest, with the number of generations a function of temperature and photoperiod (Thiéry 2008; CABI 2019). In Mendoza this pest has four generations per season, each with five larval instars. It overwinters in the pupal stage under the bark in vineyards. Adults emerge gradually in the spring and have crepuscular habits (Milonas et al. 2001; Gallardo et al. 2009). Females from the first generation lay their eggs in the flower corollas (Torres-Vila et al. 1997; Maher 2002), however females of the later generations oviposit their eggs directly on the developing grapes, with the larvae causing direct damage and the loss of commercial value due to rejections by wineries. Each female can lay approximately 100 eggs in its life. While there is little data about fecundity, mortality, and population growth rates of the European grapevine moth outside its native range, it is clear from results presented below and population growth models that the potential for population growth is staggering (Gabel and Mocko 1986; Briere and Pracros 1998; Gutierrez et al. 2012; Gilioli et at. 2016). 
The damage caused by L. botrana larvae to floral buttons, flowers and fruit is illustrated in Fig. 1. Feeding of the pest not only affects yields, but also reduces quality. Larval feeding triggers infections by the fungus Botrytis cinerea Persoon and other organisms that are the gateway to diseases such as bunch rot in the grapes. Furthermore, the presence of fungal and faecal residues of larvae cause undesirable aromas and flavours in wines that can lead to technical problems in wine making.

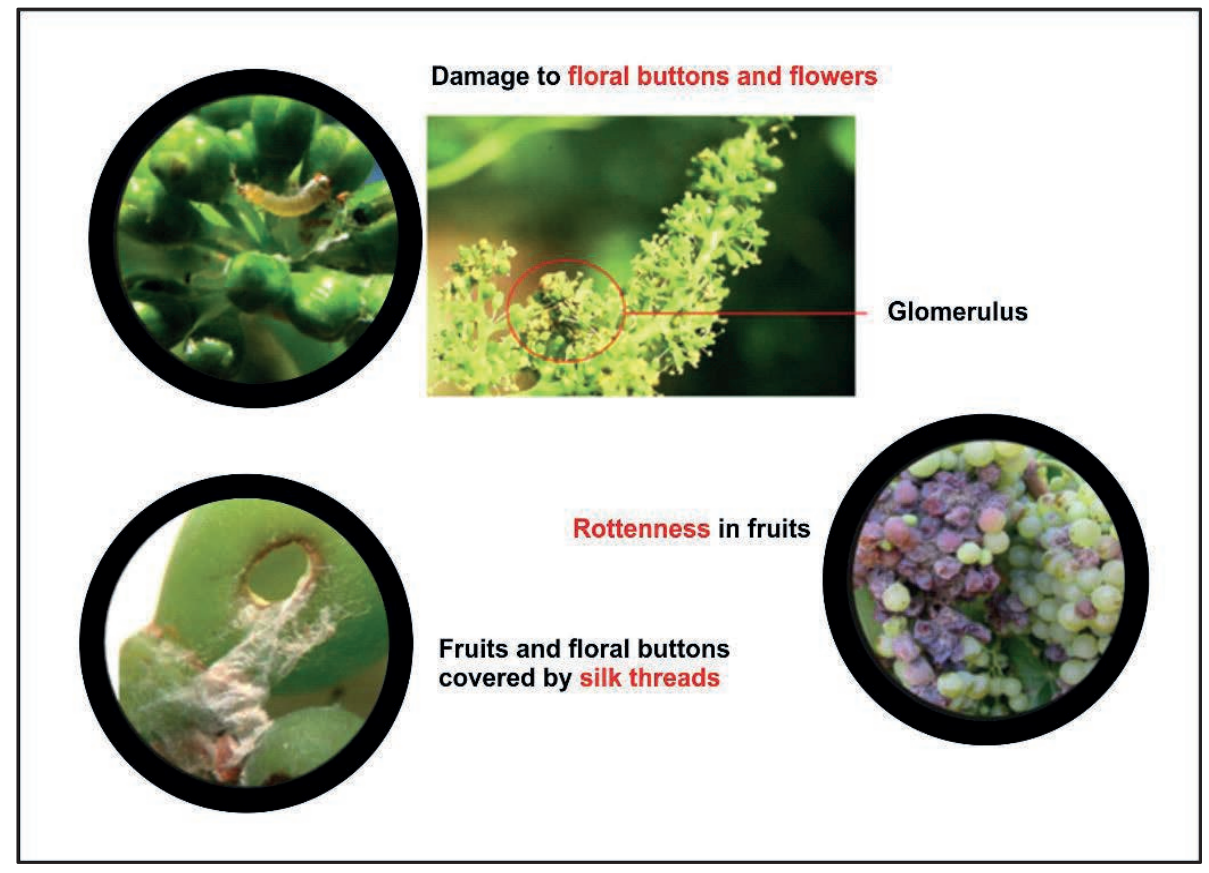

Figure 1. Damage caused by Lobesia botrana larvae to floral buttons, flowers and fruit, and the resulting bunch rot in grapes (credit ISCAMEN).

\section{SPREAD AND DISTRIBUTION OF EUROPEAN GRAPEVINE MOTH IN THE PROVINCE OF MENDOZA}

Since the initial detection of L. botrana in 2010, ISCAMEN and the Servicio Nacional de Sanidad y Calidad Agroalimentaria (SENASA) have carried out monitoring activities to obtain critical incidence data necessary for the implementation of AWIPM activities against the insect. Over 4000 pheromone-baited delta traps (E/Z 7,9 dodecadienyl acetate) are deployed in the main four oases of Mendoza Province. The traps are inspected weekly, except during the winter months when they are inspected every two weeks. ISCAMEN collects and disseminates these trapping data in the form of pest population distribution maps to support growers' pest management practices. The rapid spread of the pest in the four oasis regions until 2016 is presented in Figs. $2 \mathrm{a}, \mathrm{b}$ c. 

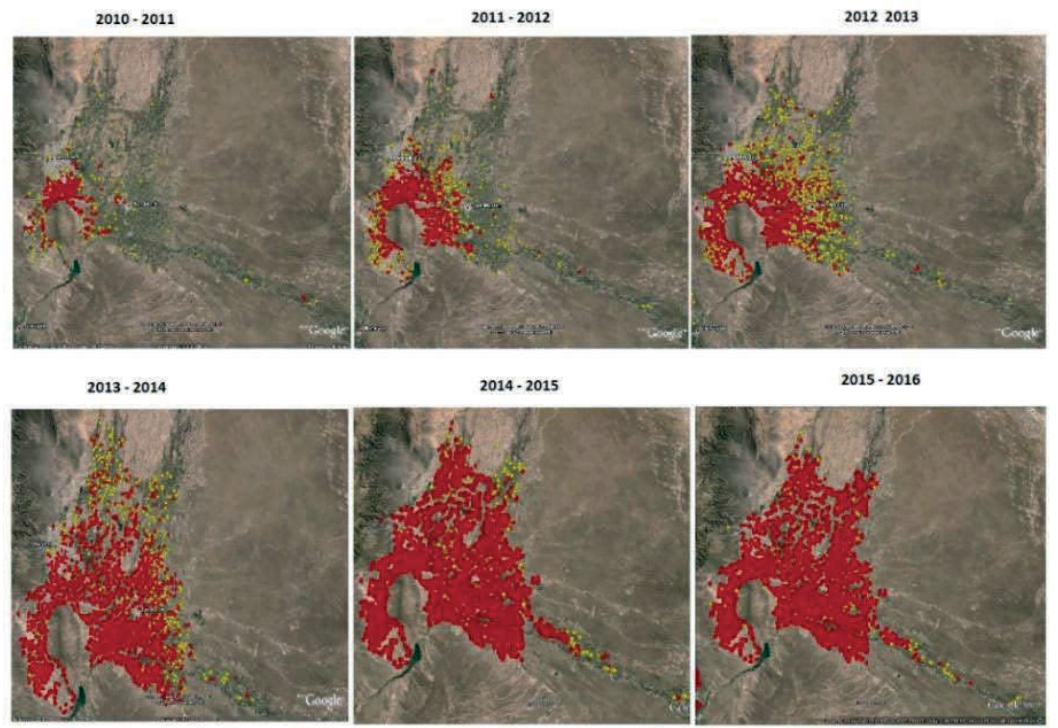

Simple catch

$\square$ Multiple catches

Figure 2a. The distribution of Lobesia botrana between 2010 and 2016 based on moth catches in the Northern and Eastern Oases of Mendoza Province, Argentina (credit ISCAMEN).
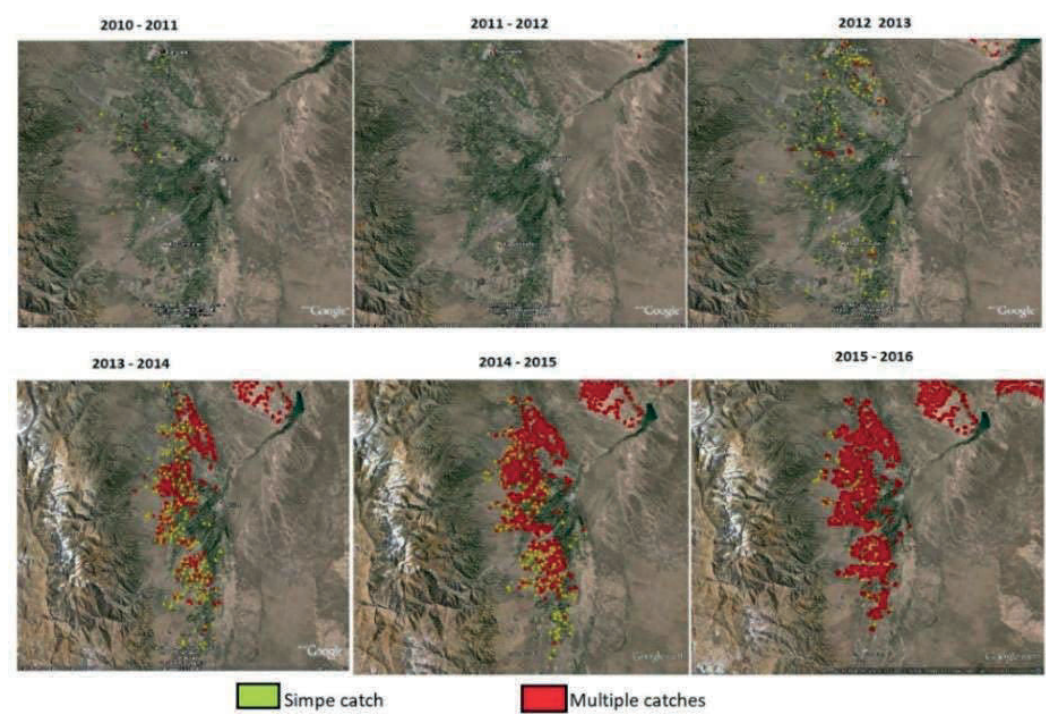

Figure 2b. The distribution of Lobesia botrana between 2010 and 2016 based on moth catches in the Central Oasis of Mendoza Province, Argentina (credit ISCAMEN). 


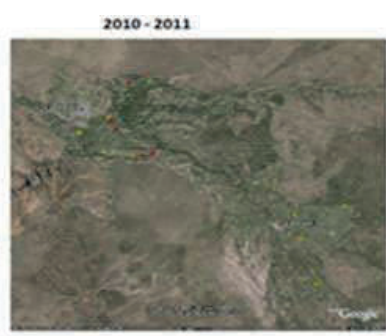

$2013 \cdot 2014$

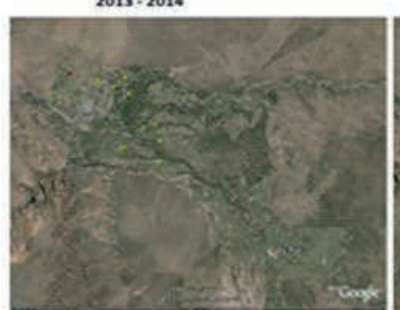

$\square$ Simpe catch
$2011 \cdot 2012$

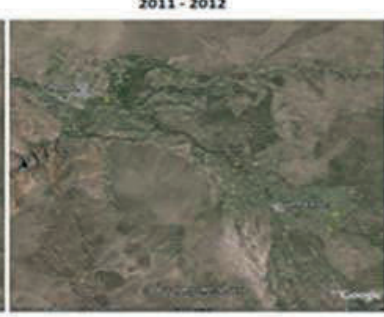

$2014 \cdot 2015$

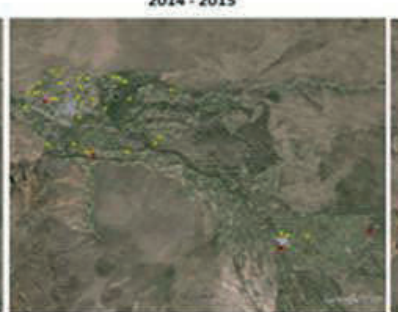

20122013

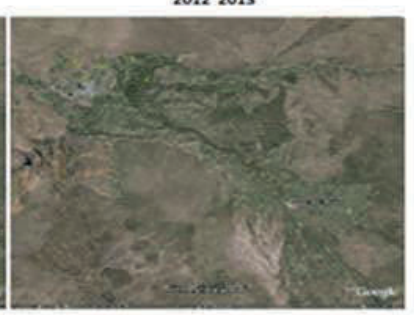

$2015-2016$

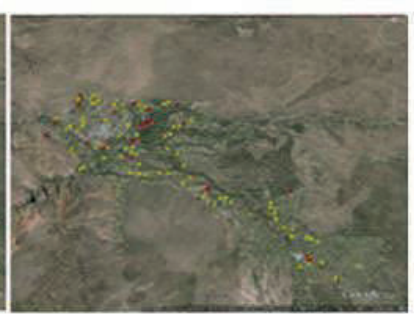

Multiple catches

Figure 2c. The distribution of Lobesia botrana between 2010 and 2016 based on moth catches in the Southern Oasis of Mendoza Province, Argentina (credit ISCAMEN).

The results of this monitoring programme indicated a rapid spread and increase of the population of the European grapevine moth, which currently infests 150000 ha of the total 160000 ha of vineyards in the Province of Mendoza.

The most affected areas are the Northern and Eastern Oases (Fig. 2a), and to a lesser extent the Central Oasis (Fig. 2b). During the last seasons, the harvested grapes in these oases have shown variable damage. This was related to factors such as the degree of susceptibility of the different varieties, and different crop and pest management systems, among others.

The damage on floral clusters and grapes have caused yield losses ranging from 10 to $70 \%$ (based on information from growers). In some situations, the damage can be $100 \%$ at harvest depending on the environmental conditions (mainly rain and humidity) and the cultivars (Moreau et al. 2006; Xuéreb and Thiéry 2006). Compared to the other areas, the Southern Oasis still has low L. botrana population levels (Fig. 2c).

\section{CONTROL STRATEGY FOR EUROPEAN GRAPEVINE MOTH IN MENDOZA: THE 2017-2018 SEASON}

Since the European grapevine moth was detected in Argentina, the official state and federal organizations promulgated Law 27.227, that formalized the establishment of a Technical Committee composed of representatives from SENASA, the Instituto Nacional de Technología Agropecuaria (INTA) and the phytosanitary agencies of the wine production provinces (Mendoza, San Juan, La Rioja, Catamarca, Tucumán, Salta, Jujuy, Río Negro, Neuquén, La Pampa, and southern Buenos Aires). 
The provinces where the pest is present (Mendoza, San Juan and Salta) coordinate control actions, while the provinces free of L. botrana focus on detection and quarantine activities (controlling the movement of trucks with grapes or containers used during harvesting, or harvest machines to avoid risk of dispersal).

The same law also established a Technical Advisory Committee (TAC) with technical members of the above-mentioned organizations, along with members of the Asociación de Cooperativas Vitivinícolas Argentinas (ACOVI), the Corporación Vitivinícola Argentina (COVIAR), the Federación de Cooperativas Vitivinícolas Argentinas (FECOVITA), the Instituto Nacional de Semillas (INASE), the Instituto Nacional de Vitivinicultura (INV), Argentina's wineries, association of table grape growers and others.

Using the results obtained in the previous seasons and the current pest status, the TAC developed a management strategy for each oasis of the province for the 2017 2018 season. This was authorized by SENASA after thorough evaluation and verification that these were compliant with the requirements of the national programme. The TAC also established protocols for monitoring, assessment of fruit damage, movement of fruit inside and outside the affected production and regulated areas, and sanitary controls within the quarantine areas.

Growers needed to register with the programme to receive assistance and the necessary control items and products. A total of 7903 growers were registered covering 11400 properties over a total area of 132674 ha of vineyards (Table 1). These numbers, out of the total 160000 ha of vineyards, epitomize the severity of the L. botrana problem for the grape and wine industries.

Public and private entities were involved in providing training to this large number of growers that included workshops given to growers, technicians, professionals and winery owners. The training was essential to ensure the correct use of the control tools. A total of USD 20 million was invested to enable implementation of the management programme in the affected provinces.

Table 1. Number of vineyards, surface area and number of growers participating in the Lobesia botrana management programme in the oases of Mendoza

\begin{tabular}{|c|c|c|c|}
\hline Oasis & $\begin{array}{c}\text { Number of } \\
\text { Vineyards }\end{array}$ & $\begin{array}{c}\text { Area } \\
\text { (ha) }\end{array}$ & $\begin{array}{c}\text { Number } \\
\text { of Growers }\end{array}$ \\
\hline $\begin{array}{c}\text { Northern and } \\
\text { Eastern }\end{array}$ & 7689 & $89392^{*}$ & 4503 \\
\hline Central & 1356 & 25601 & 1002 \\
\hline Southern & 2972 & 17681 & 2398 \\
\hline
\end{tabular}

*Of which approximately 25000 ha are abandoned or semi-abandoned, requiring special attention by SENASA 


\section{CONTROL TOOLS USED}

\subsection{Mating Disruption}

The decision to use mating disruption for supressing L. botrana in the Province of Mendoza was made because it is species-specific and there is an extremely low risk of developing resistance to the pheromone blend (although see Mochizuki et al. 2002). It does not produce insecticide residues, does not affect the beneficial fauna, and thereby limits the appearance of secondary pests. It is also compatible with other control methods and is accepted for use in organic orchards (Pérez Marín et al. 1995).

Mating disruption works by releasing synthetic versions of the sex-pheromones that female L. botrana use to attract con-specific males (Cardé, this volume). Pheromone dispensers release pheromone plumes that confuse the males. Though the exact mechanism(s) of mating disruption is debated, be it habituation to the pheromone, attenuation of the sensory organs, false trail following, or trail masking, it is clear that this technique reduces mating frequency and/or delays mating in such a way as to reduce overall fecundity, resulting in decreased damage to the grapes.

The semipermeable polymer of the pheromone dispensers (RAK from BASF or ISONET from Shin-Etsu) releases the pheromone mix at a constant rate, depending on the temperature and humidity, for a period of 6 months. This provides protection of the crop for 180 to 200 days, which covers the entire grape season. Pheromone dispensers must be deployed before the onset of adult activity in the season (September is the first flight of L. botrana in Mendoza, see Fig. 3) and they need to be evenly distributed in the vineyards at a density (typically 350 dispensers per ha).

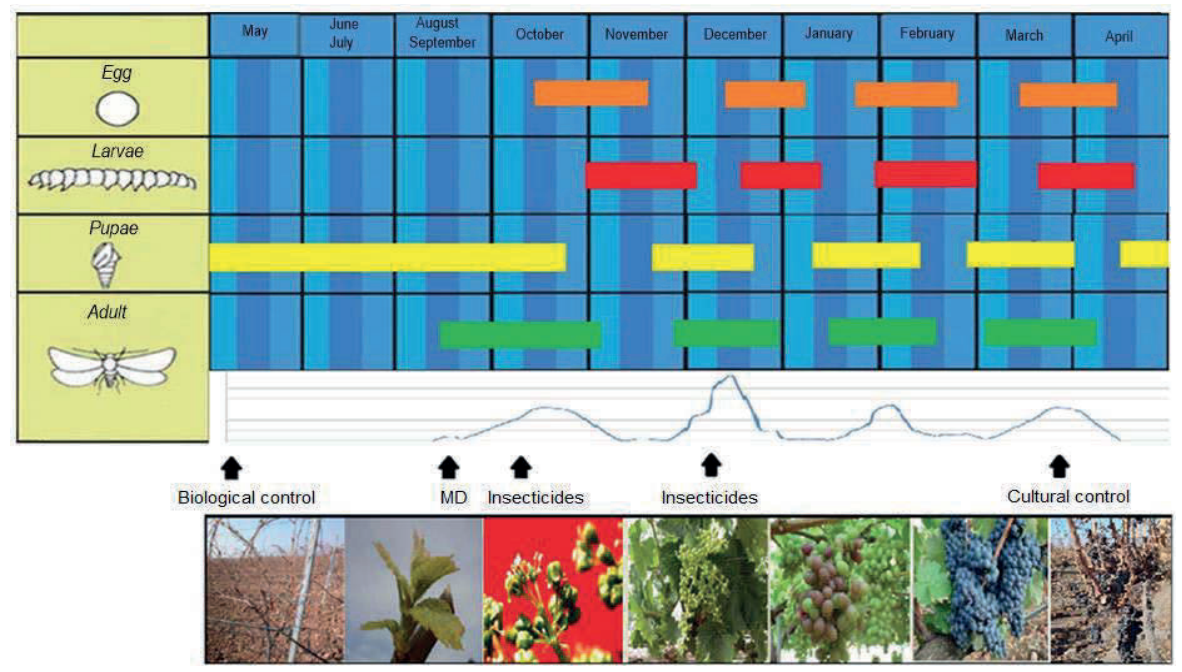

Figure 3. Scheme of a growing season illustrating the best time for applying the different control methods in relation to the biological life cycle of Lobesia botrana and the development of the crop in Mendoza Province (MD= mating disruption) (credit ISCAMEN). 
Depending on the pest pressure, however, mating disruption may need to be supplemented with insecticide applications to control the immature stages of the insect. Mating disruption is a density-dependent management tool, being less effective when pest populations are high, or when there are untreated areas with migration of moths into nearby mating disruption-treated areas. Mating disruption is a fundamental control tactic for the European grapevine moth in all countries where it is present (Del Tío et al. 2001; Louis et al. 2002; Vassiliou 2009; Ioriatti et al. 2011). It was also one of the main components for achieving the eradication of the outbreak of this pest in northern California, USA (Mastro et al. 2010a, b, c; Varela et al. 2010; Lance et al. 2011; Lucchi et al. 2014; Simmons et al., this volume).

The Ministry of Agribusiness of the Nation procured 22 million mating disruption dispensers at a total cost of USD 9344 500, which was enough to cover 62857 ha. This amount was supplemented with USD 400000 from the Province of Mendoza, which was enough to procure an additional 1094390 dispensers covering an area of approximately 3126 ha. In the 2017-2018 growing season, mating disruption was therefore used on 65983 ha of vineyards to manage populations of the European grapevine moth.

In the 2018-2019 season, the state again invested USD 7.2 million to cover 60000 ha (120 USD/ha) with pheromone dispensers. In some areas, mating disruption was used as a single control tactic, whereas in others, it was combined with the application of specific insecticides for immature stages depending on the population levels. When populations remained below a seasonal average of 10 moths per day, only mating disruption was used. When more than 10 moths were caught, immature stages were suppressed with insecticide applications.

\subsection{Aerial Applications of Pheromones}

An alternative to hand-applied, polymer mating disruption dispensers is a flowable formulation that can be rapidly applied aerially. The product is a suspension of encapsulated particles containing $19.2 \% \mathrm{w} / \mathrm{v}$ of the active ingredient (E/Z 7,9 dodecadienyl acetate). This product, if applied correctly, effective interrupts matings for 30-60 days from the moment of its aerial application over the crop. The pheromone is applied at the beginning of the second flight, in mid to late November for Mendoza Province (Fig. 4).

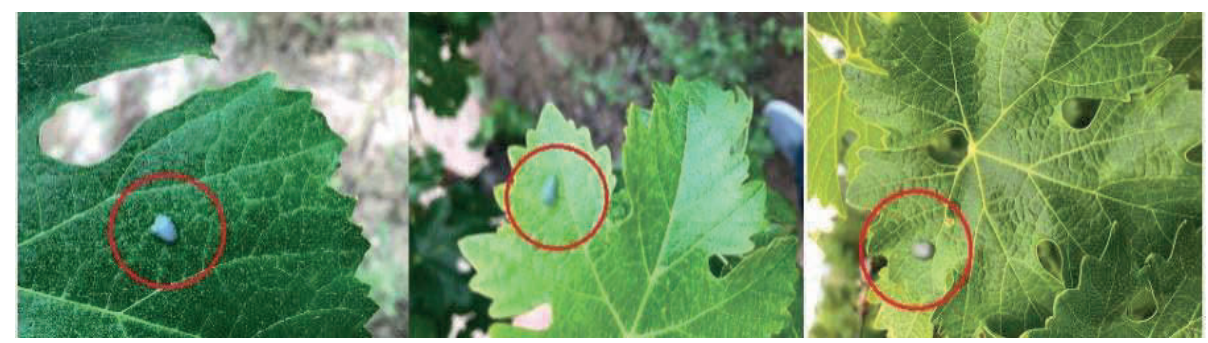

Figure 4. Drops with pheromones on the crop foliage (credit ISCAMEN). 
Flowable mating disruption does not last as long as polymer dispensers, however, aerial application allows for rapid, area-wide coverage, in response to building populations. This approach is also ideal to control moth populations in abandoned, semi-abandoned farms or mismanaged vineyards. These are the main refuges for this pest, where it proliferates and then emigrates to the treated orchards. No phytotoxicity symptoms were observed during its application (Fig. 4). The trapping data of the areas under treatment confirmed its effectiveness (Fig 5).

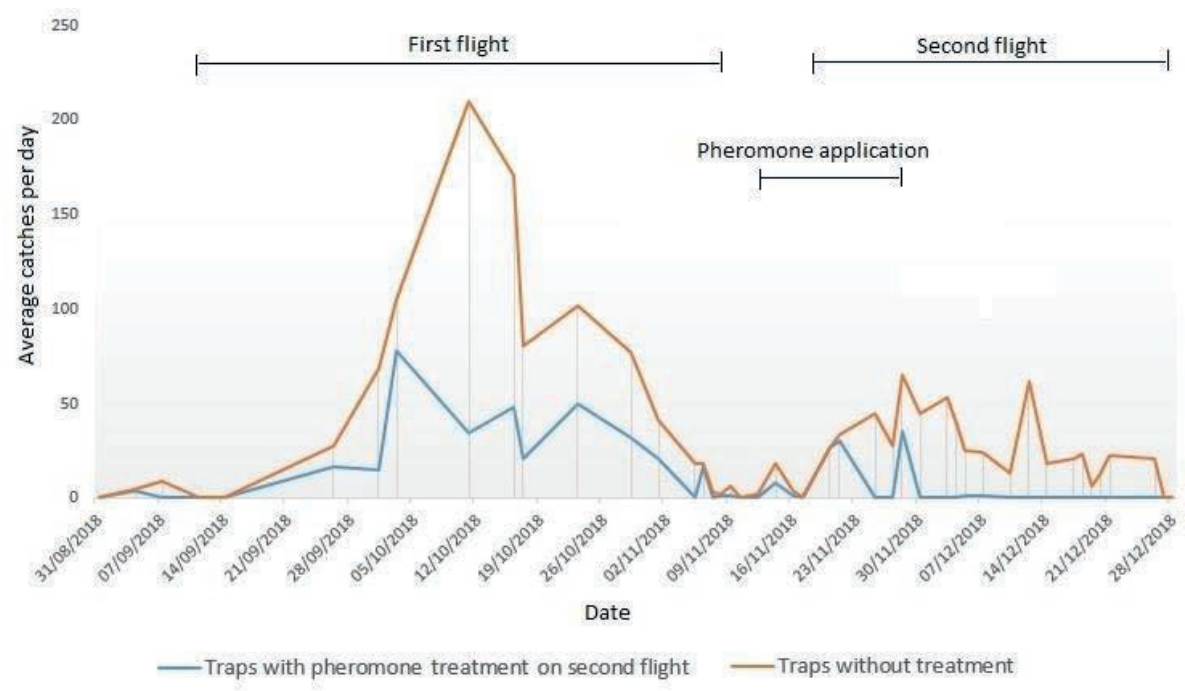

Figure 5. Effect of aerial pheromone sprays on the average catches of Lobesia botrana per trap in areas with and without mating disruption treatment (credit ISCAMEN).

\subsection{Insecticides for the Control of Immature Stages}

The invasion of European grapevine moth required the use of insecticides to control larval stages of the pest even though these historically have not been used in vineyards of the Province of Mendoza. Chemical control may be a necessary suppression tactic of agricultural pests in the framework of IPM, complementing biologically-based methods, such as biological control, mating disruption, together with mechanical and cultural controls.

In view of the characteristics of the host crop (grapes), and taking into consideration the importance of protecting the beneficial fauna in the vineyards, the proposed phytosanitary products to suppress immature $L$. botrana had to conform to the following characteristics (and hence, being compatible with an AW-IPM approach): 1) low environmental impact, 2) specificity for the control of the target pest; 3) no effect on pollinators; and 4) no risks to human health.

Aerial and ground applications of the selective insecticide Coragen ${ }^{\circledR}$ (chlorantraniliprole or rynaxpyr, an anthranilic diamide insecticide) were used over 138000 ha of vineyards to control immature stages of the first generation of the pest. 
In addition, the biological product Dipel DF ${ }^{\circledR}$ (Bacillus thuringiensis kurstaki) was applied by air over 68000 ha of vineyards to control the immature stages of the first or second generation of the pest.

Finally, the selective insecticide Proclaim Forte ${ }^{\circledR}$ (emamectin benzoate, an avermectin insecticide, derived from a metabolite of the bacterium Streptomyces avermitilis Kim and Goodfellow) was applied from the ground over 14500 ha of vineyards to control immature stages of the second generation. Both Coragen and Dipel DF were already registered with SENASA for aerial applications on different crops.

In the 2018/2019 growing season, the products Delegate (active ingredient spinetoram) and Intrepid SC (active ingredient methoxyfenozide) were also used over large areas as part of the control strategy (Sáenz de Cabezón et al. 2005). Growers used Delegate for ground spraying, whereas Intrepid SC was mainly used for aerial application to target the first generation of immature stages.

\subsection{Aerial and Ground Application of Insecticides}

\subsubsection{Advantages of Aerial Application of Chemical and Biological Products}

To obtain effective management of L. botrana, it is essential to apply the phytosanitary products during the various periods of insect susceptibility (Fig. 3). However, the growers of the affected areas are limited to ground spraying as they have no access to appropriate levels of mechanization. Since the detection of the pest in 2010, and depending on the available financial resources, SENASA assisted the growers in managing populations of $L$. botrana with insecticides of low environmental impact. Furthermore, it was essential to apply aerial sprays to the abandoned vineyards.

The aerial application of insecticides has several advantages, such as 1) to allow an area-wide strategy, covering commercial as well as abandoned or semi-abandoned orchards, 2) the control can be applied rapidly to target the most vulnerable stage of the pest, 3) the number of ground applications is significantly reduced, 4) the treatments with aircraft are traceable / auditable, as the aerial sprays are monitored and continuously registered with appropriate GPS technology, 5) the spray mixtures are prepared by a small number of highly trained professionals, rather than a large number of growers who infrequently mixed insecticides in the past, reducing the likelihood of errors in the application rate, 6) the aerial spraying is cost-effective and the application volumes and the quantity of active ingredient applied are significantly reduced per unit of surface, 7) the use of GPS technology allows the aircraft to interrupt the application over specific areas such as rural houses, and, 8) satellite imagery allows determining the criteria and application blocks at a geographic scale, as well as proper coordination of operations.

Prior to the aerial treatments, the planned activities are discussed and agreed upon with each community. The aerial operations require ground support equipment, and the phytosanitary organizations take samples to determine areas that need or don't need treatments. The data are communicated to the general public to ensure transparency. Provincial phytosanitary organizations assess population levels of the pest for each zone and the treatment products required for the aerial spraying. 
A summary of the control strategy used during the 2018-2019 season, integrating the different control systems, are shown in Fig. 6. The products Coragen and Intrepid, are not certified for use in organic vineyards complying with NOP (National Organic Programme) norms established for exports to the USA. These products were not used when treating conventional orchards adjacent to NOP vineyards to avoid the possible drift of these insecticides. Mating disruption has been the focus in the control of the pest in the vineyards with organic certifications or NOP standards.

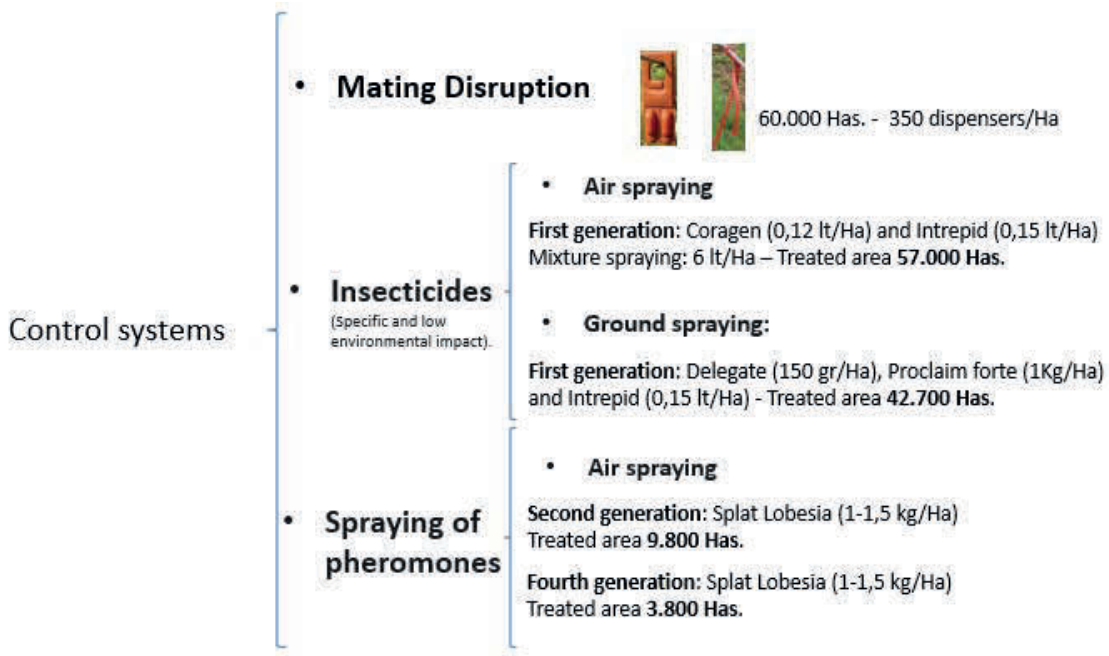

Figure 6. Strategy used for the control of Lobesia botrana for the 2018/2019 season, in working areas based upon data from the monitoring programme.

\subsubsection{Ground Spraying of Chemicals by the Growers}

Ground spraying by growers is used exceptionally and only in peri-urban areas or close to buildings where aerial applications are prohibited. For timing of interventions see Fig. 3:

- First alert: The appearance of eggs of the first generation of the pest when the floral clusters of the crop are being formed (length of 5-7 cm) signals the opportune moment to carry out the first treatment against immatures. This occurs in midOctober, depending on temperatures and the status of varieties in each area. Coragen was the product selected for controlling the first generation of the pest in ca. 23000 ha and 42700 ha in the 2017/2018 and 2018/2019 campaigns, respectively.

- Second alert: The timing of chemical treatments against the immatures stages of this second generation is zone-dependent and is influenced by the population dynamics of the pest, field surveys, and thermo-cumulative models. The starting date for treatment of the second generation of the pest has been around the middle of December. Proclaim Forte was the choice for the control of this generation of the pest in an area of ca. 18500 ha during the 2017/2018 campaign. 


\subsection{Cultural Control}

The main objective of cultural control is to prevent the insect completing its life cycle by removing infested grape clusters. The critical role of growers doing this postharvest control is essential to managing this pest. Also, growers have to avoid the movement and transport of pruning wastes, as they can contain dormant stages of $L$. botrana. The implementation of these measures is supervised by the local phytosanitary organizations.

\section{RESULTS OF CONTROL ACTIVITIES}

\subsection{Impact of Aerial Spraying against Immatures}

The impact of aerial sprays on the pest population is shown in Fig. 7. It displays average weekly moth catches with 60 traps during the 2016/2017 season, when aerial spraying was not carried out, and during the 2017/2018 season when aerial spraying against immatures took place. The data clearly indicate a reduction in the population density of generations 2, 3 and 4. This is evidence of the benefit of an area-wide approach using aerial spraying combined with preventive control earlier in the season for this multivoltine species.

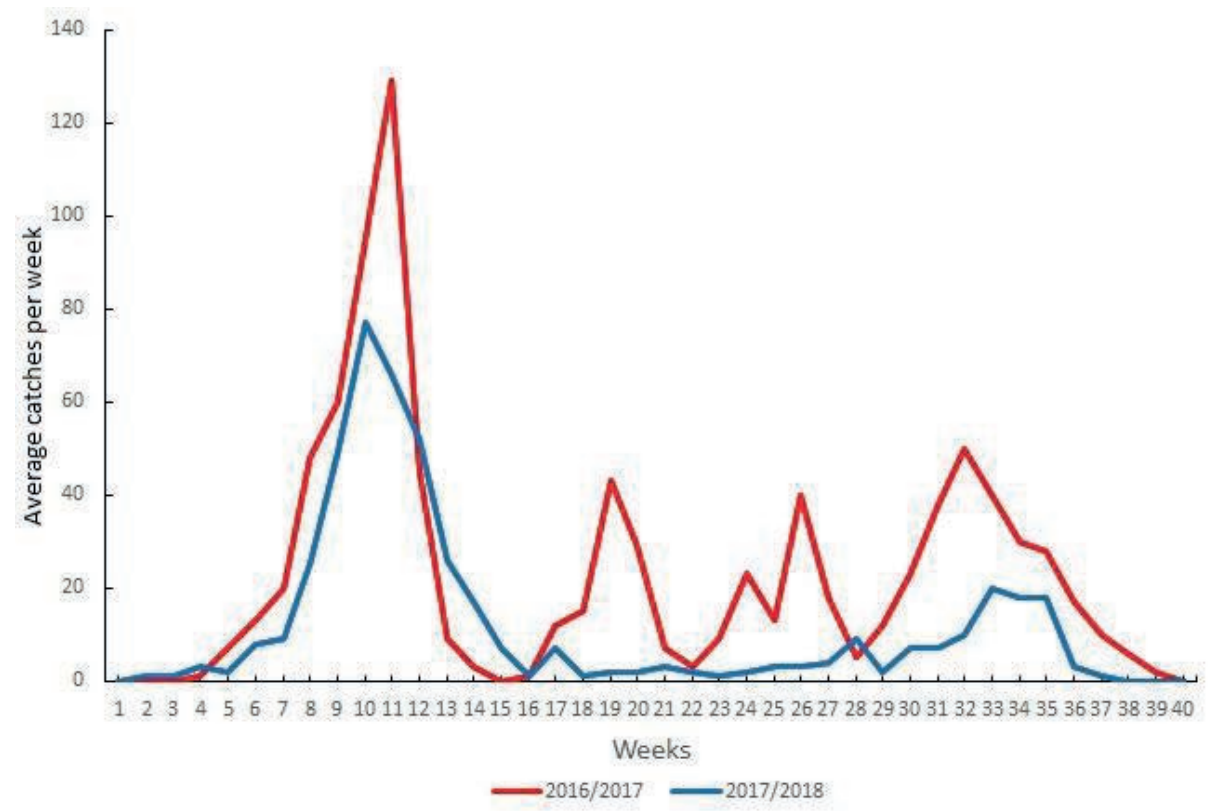

Figure 7. Average weekly catches of Lobesia botrana with 60 traps during the 2016/2017 season (without aerial spraying) and during the 2017/2018 season (with aerial spraying against immatures in the first and second generations) in the Province of Mendoza. 


\subsection{Management of Lobesia botrana since the 2016/2017 Season}

\subsubsection{Northern and Eastern Oases}

$A$ t the end of the 2016-2017 season the pest was heterogeneously distributed throughout the Northern and Eastern Oases over a total area of approximately 50000 ha (Fig. 8). Our experiences of using mating disruption as a control tactic, and those of other programmes, indicate the need for continuous treatment of the areas to achieve sustained reductions in the pest population (Cardé, this volume).

In the Northern and Eastern Oasis, mating disruption in the 2017/2018 and $2018 / 2019$ seasons was applied over a total of almost 40000 ha using fixed pheromone dispensers and in the 2018/2019 season over 14000 ha with one aerial application of the pheromone. These areas were also treated with the aerial application of chemical/biological insecticides to control immatures resulting from the first flight of the insect. In the remaining 48000 ha of the Northern-Eastern Oasis, chemical/biological products were sprayed by air and from the ground for the control of the first and second flight during the 2017-2018 and 2018-2019 seasons.

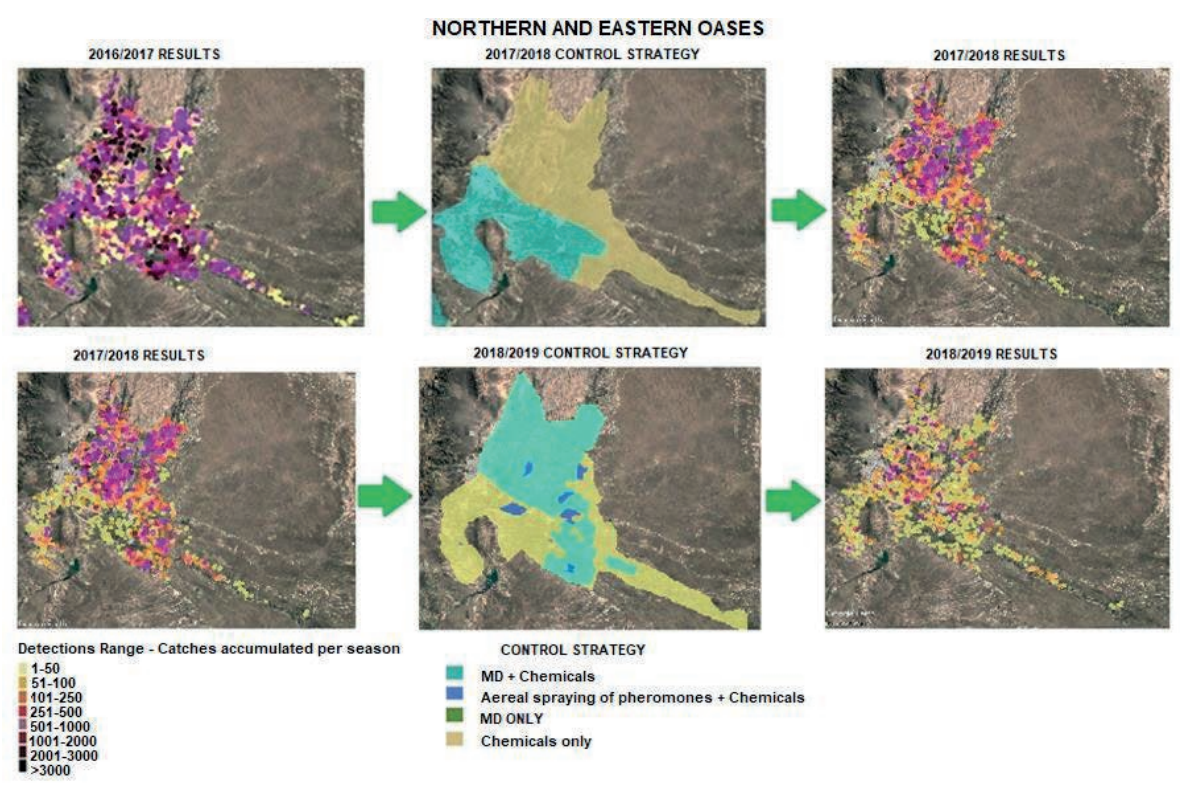

Figure 8. Distribution and levels of Lobesia botrana populations in the Northern and Eastern Oases and control measures used in the 2016/2017, 2017/2018 and 2018/2019 seasons (credit ISCAMEN).

\subsubsection{Central Oasis}

Based on the monitoring data of the 2016/2017 season, the Central Oasis showed a uniform distribution of the pest (Fig. 9). As in the northern and eastern Oases, the strategy was defined in accordance to the distribution and population density of the pest. 
The Central Oasis has approximately 26000 ha of vineyards and L. botrana is present throughout the entire area. During the 2017-2018 and 2018-2019 seasons different control tactics such as mating disruption and chemical control of the immature stages of the first generation were combined in areas with the highest population pressure. In the rest of the oasis, only chemical control was applied against the immature stages during the first and second flights of the pest.

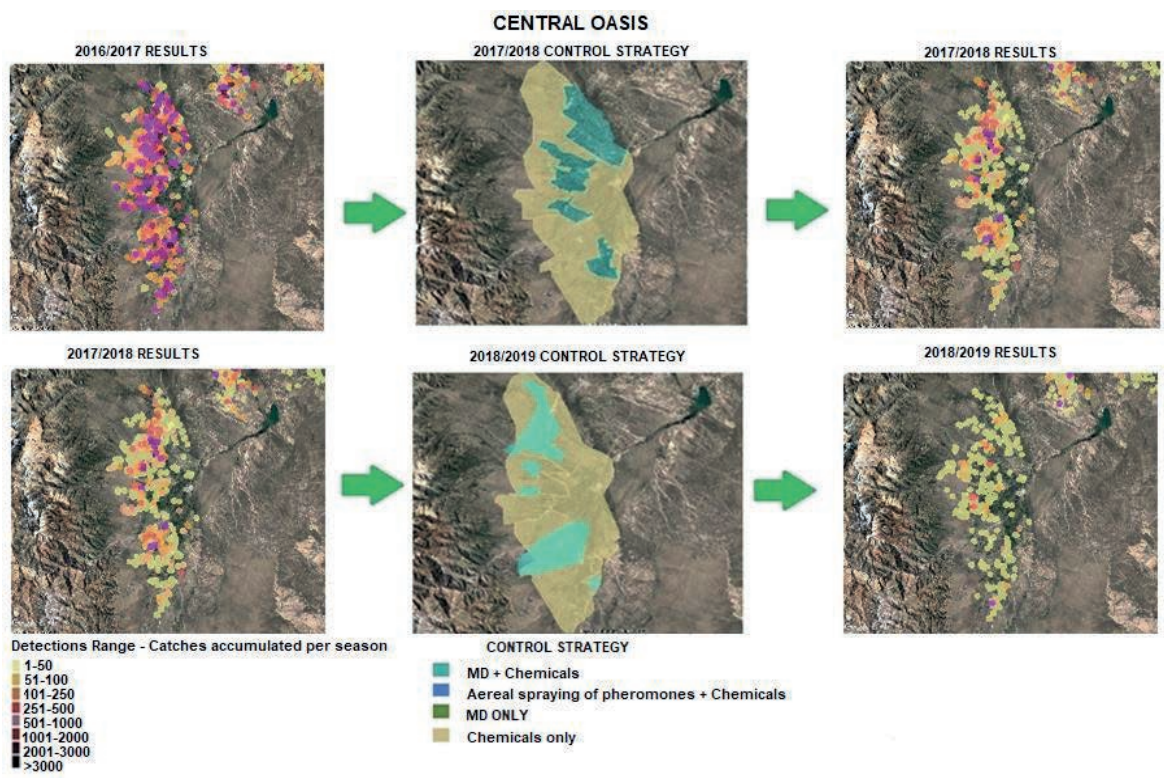

Figure 9. Distribution and levels of Lobesia botrana populations in the Central Oasis and control measures used in the 2016/2017, 2017/2018 and 2018/2019 seasons (credit ISCAMEN).

\subsubsection{Southern Oasis}

Population densities of the pest in the Southern Oasis 2016/2017 season were significantly lower than those observed in the Central and Northern-Eastern Oases (Fig. 10).

In the Southern Oasis the pest has been detected so far in 10000 ha out of a total of 16000 ha of vineyards. During the 2017/2018 season mating disruption was used over the entire area. During the 2018/2019 season, the densities of the pest insect were very low, and therefore it was decided to use only mating disruption in all infested areas, and to continuously monitor in the remaining zones. 


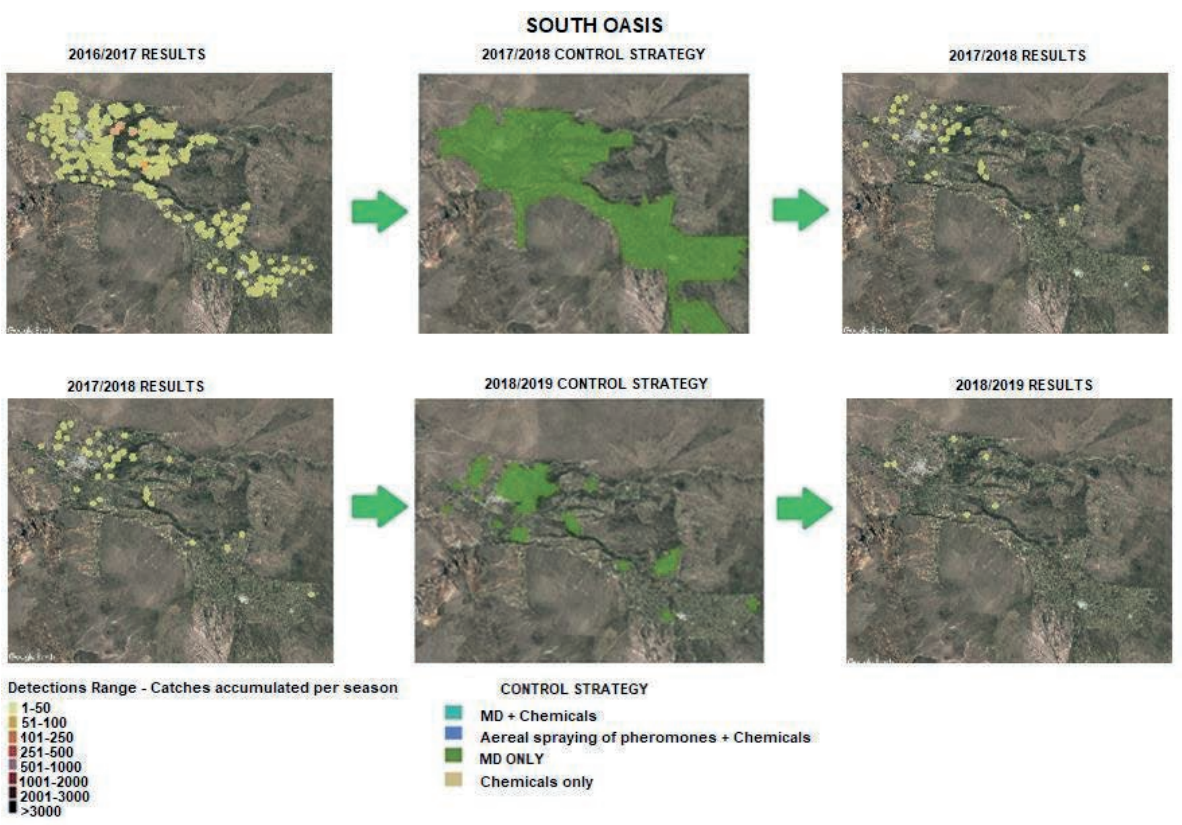

Figure 10. Distribution and levels of Lobesia botrana populations in the Southern Oasis and control measures used in the 2016/2017, 2017/2018 and 2018/2019 seasons (credit ISCAMEN).

\subsection{Additional Activities during the 2017-2018 and 2018-2019 seasons}

In the 2017/2018 and 2018/2019 seasons, mating disruption dispensers were applied as outlined above (see also Section 6.4.). However, there were several exceptions:

1. Table grapes growers who were registered in the framework of the IPM programme were also provided with mating disruption dispensers to minimize the risks of the pest dispersing to wine grape growing areas.

2. Mating disruption dispensers were provided to growers of table or organic wine grapes whose vineyards were smaller than 5 ha to ensure global coverage of mating disruption.

3. Certified organic growers (NOP certification) or growers who were transitioning from traditional to organic production were provided with mating disruption dispensers for their local deployment.

\subsection{Comparison of Trap Catches in the Last Seasons}

The comparison of $L$. botrana trap catches in the last nine seasons is presented in Fig. 11. According to the results obtained from the same 4200 traps kept from the first season to the end of the 2018/2019 season, an overall reduction of the target pest populations was reached. Nevertheless, there are still some foci where the actions must be intensified. 


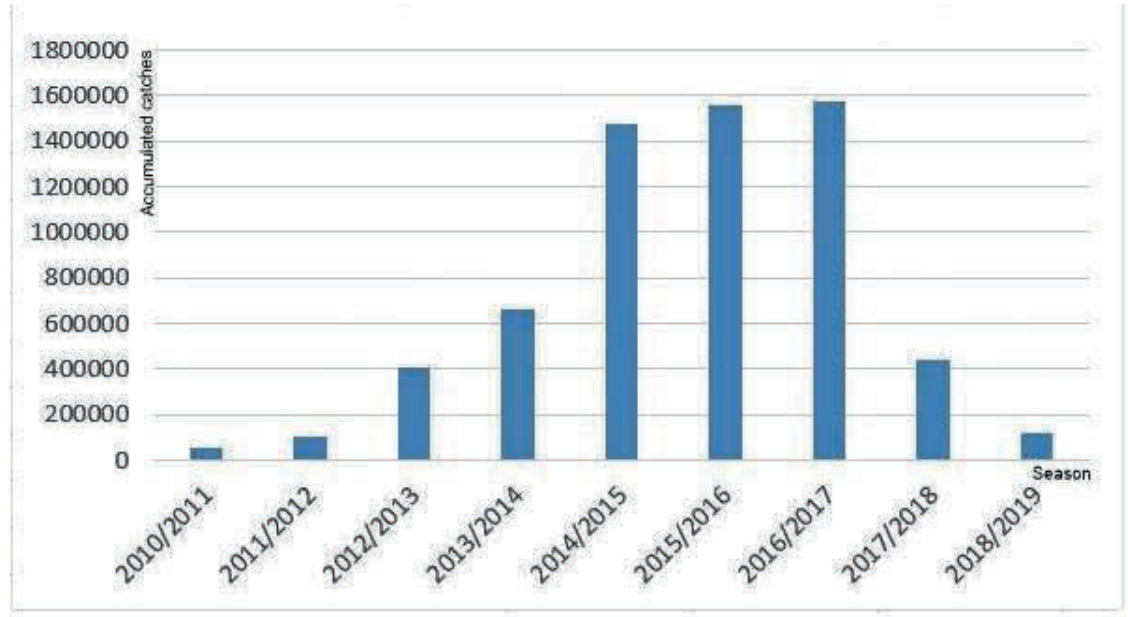

Figure 11. Comparison of total Lobesia botrana captures per season in the Province of Mendoza from the 2010/2011 the 2018/2019 season.

As in other insects with similar population dynamics, the control of the first generation of the insect will determine the level of pest population built-up later in the season, and therefore determines grape damage. Although these trap data are partially affected by the pheromones and other control measures applied, the reduction in the number of trap catches is an indicator of the effectiveness of the area-wide mating disruption. Some areas of the Southern Oasis begin to show discontinuity in wild moth catches even in the absence of any other kind of treatment, an indication of the potential towards achieving the final objective of eradication.

\section{DEVELOPMENT OF BIOLOGICAL CONTROL AND STERILE INSECT TECHNIQUE AS ALTERNATIVE CONTROL SYSTEMS}

During the last two years (starting in 2018), Argentina through ISCAMEN, has also been assessing the potential of integrating other control methods that are friendly to the environment. These are biological control and the Sterile Insect Technique (SIT) that are under development.

Biological control, through the mass-rearing and augmentative release of Trichogramma sp. is being developed at ISCAMEN's Pilot Experimental Unit. The efficiency of the microhymenopteran egg parasitoid was assessed on eggs of Grapholita molesta (Busck) eggs; however, eggs of L. botrana have also been parasitized.

On the other hand, research on the SIT has been initiated by developing the massrearing for L. botrana. Wild material was collected from the field and a colony established. The eggs collected from oviposition cages were evaluated in terms of egg hatch. A specific larval diet was used and evaluated in terms of the percentage recovery from eggs to adults. Further studies include the development of a system to 
separate mature larvae/pupae from the larval diet, determination of the irradiation dose, and methods for sterile moth packaging and release systems.

During the 2019/2020 season, sterile moths, produced at an ISCAMEN pilot facility, are being released in a 27 -ha commercial vineyard. Recapture data are being collected and analysed to determine the optimal relationship between sterile males and wild $L$. botrana moths for increased SIT application.

Eventually the integration of the SIT, augmentative biological control and mating disruption could be validated as an insecticide-free IPM programme for the suppression of L. botrana.

\section{REFERENCES}

Armendáriz, I., G. Campillo, A. Pérez-Sanz, C. Capilla, J. S. Juárez, and L. Miranda. 2007. La polilla del racimo (Lobesia botrana) en la D.O. Arribes, años 2004 a 2006. Boletín de Sanidad Vegetal Plagas 33: 477-489.

Briere, J.-F., and P. Pracros. 1998. Comparison of temperature-dependent growth models with the development of Lobesia botrana (Lepidoptera: Tortricidae). Environmental Entomology 27: 94-101.

CABI. 2019. Lobesia botrana (European grapevine moth). Invasive Species Compendium.

Coscollá Ramón, R. 1981. Algunas consideraciones sobre la dinámica poblacional de Lobesia botrana Den. \& Schiff. en las comarcas vitícolas valencianas. Boletín Servicios Plagas 7: 169-184.

Coscollá Ramón, R. 1998. Polillas del racimo (Lobesia botrana Den. \& Schiff.). pp. 29-42. In Los parásitos de la vid, estrategias de protección razonada. Madrid, Spain.

Del Tío, R., J. L. Martínez, R. Ocete, and M. E. Ocete. 2001. Study of the relationship between sex pheromone trap catches of Lobesia botrana (Den. \& Schiff.) (Lep., Tortricidae) and the accumulation of degree-days in Sherry vineyards (SW of Spain). Journal of Applied Entomology 125: 9-14.

Gabel, B., and V. Mocko. 1986. A functional simulation of European vine moth Lobesia botrana Den. \& Schiff. (Lep., Torticidae) population development. Journal of Applied Entomology 101: 121-127.

Gallardo, A., R. Ocete, M. A. López, L. Maistrello, F. Ortega, A. Semedo, and F. J. Soria. 2009. Forecasting the flight activity of Lobesia botrana (Denis \& Schiffermüller) (Lepidoptera, Torticidae) in Southwestern Spain. Journal of Applied Entomology 133: 626-632.

Gilioli, G., S. Pasquali, and E. Marchesini. 2016. A modelling framework for pest population dynamics and management: An application to the grape berry moth. Ecological Monitoring 320: 348-357.

González, R. H. 2008. Biología, desarrollo, caracterización de daños y manejo fitosanitario de la polilla europea de la vid, Lobesia botrana (D \& S) (Lep., Tortricidae). Universidad de Chile, Dirección de Extensión, Santiago, Chile. 25 pp.

Gutierrez, A. P., L. Ponti, M. L. Cooper, G. Gilioli, J. Baumgärtner, and C. Duso. 2012. Prospective analysis of the invasive potential of the European grapevine moth Lobesia botrana (Den. \& Schiff.) in California. Agricultural and Forest Entomology 14: 225-238.

Ioriatti, C., A. Lucchi, and L. G. Varela. 2012. Grape berry moths in Western European vineyards and their recent movement into the New World, pp. 339-359. In N. J. Bostanian, C. Vincent, and R. Isaacs (eds.), Arthropod Management in Vineyards: Pests, Approaches, and Future Directions. Springer Science + Business Media B.V.

Ioriatti, C., G. Anfora, M. Tasin, A. De Cristofaro, P. Witzgall, and A. Lucchi. 2011. Chemical ecology and management of Lobesia botrana (Lepidoptera: Tortricidae). Journal of Economic Entomology 104: 1125-1137.

Lance, D., R. T. Cardé, M. Cooper, A. Lucchi, L. Sazo, G. Simmons, R., Steinhauer, and L. G. Varela. 2011. Fourth report of the USDA APHIS International Technical Working Group for the European grapevine moth (EGVM) in California, USA. December 13-15, 2011.9 pp.

Louis, F., A. Schmidt-Tiedemann, and K. J. Schirra. 2002. Control of Sparganothis pilleriana Schiff. and Lobesia botrana (Den. \& Schiff.) in German vineyards using sex pheromone-mediated mating disruption. Bulletin IOBC/WPRS 25: 1-9.

Lucchi, A., B. Bagnoli, M. Cooper, C. Ioriatti, and L. Varela. 2014. The successful use of sex pheromones to monitor and disrupt mating of Lobesia botrana in California, pp. 45-48. In Pheromones and other semiochemicals. Bursa, Turkey, 2012. IOBC-WPRS Bulletin 99. 
Maher, N. 2002. Sélection du site de ponte chez Lobesia botrana (Lepidoptera: Tortricidae): Influence de l'information chimique non-volatile présente sur les fruits de plantes hôtes. Thése $\mathrm{N}^{\circ} 968$, Université de Bordeaux 2. pp. 204.

Mastro, V., B. Bagnoli, R. T. Cardé, G. Wegner-Kiss, C. Ioriatti, U. Koch, D. Lance, A. Lucchi, G. Barrios, L. Sazo, R. Sforza, R. Steinhauer, and L. G. Varela. 2010a. First report of the USDA APHIS International Technical Working Group for the European grapevine moth (EGVM) in California, USA. February 10, 2010. 10 pp.

Mastro, V., R. T. Cardé, D. Lance, A. Lucchi, L. Sazo, R. Steinhauer, and L. G. Varela. 2010b. Second report of the USDA APHIS International Technical Working Group for the European grapevine moth in California, USA. May 14, 2010. 6 pp.

Mastro, V., R. T. Cardé, C. Ioriatti, D. Lance, A. Lucchi, L. Sazo, G. Simmons, R. Steinhauer, and L. G. Varela. 2010c. Third report of the International Technical Working Group for the European grapevine moth in California, USA. December 7, 2010. 7 pp.

Milonas, P. G., M. Savopoulou-Soultani, and D. G. Stavridis. 2001. Day-degree models for predicting the generation time and flight activity of local populations of Lobesia botrana (Den. \& Schiff.) (Lep., Tortricidae) in Greece. Journal of Applied Entomology 125: 515-518.

Mochizuki, F., T. Fukumoto, H. Noguchi, H. Sugie, T. Morimoto, and K. Ohtani. 2002. Resistance to a mating disruptant composed of (Z)-11-tetradecenyl acetate in the smaller tea tortrix, Adoxophyes honmai (Yasuda) (Lepidoptera: Tortricidae). Applied Entomology and Zoology 37 (2): 299-304.

Moreau, J., B. Benrey, and D. Thiéry. 2006. Grape variety affects larval performance and also female reproductive performance of the European grapevine moth Lobesia botrana (Lepidoptera: Tortricidae). Bulletin Entomological Research 96: 205-212.

Pérez Marín, J. L., C. Ortega Sáenz, E. Palacios Ruiz, and C. Gil-Albarellos Marcos. 1995. Un nuevo método de control de la polilla del racimo de la vid: la confusión sexual. Boletín de Sanidad Vegetal Plagas 21: 627-640.

(SAG) Servicio Agrícola y Ganadero. 2010. Modifica resolución $\mathrm{N}^{\circ} 2.109$, de 2008, que declara control obligatorio de la polilla del racimo de la vid (Lobesia botrana). Ministerio de Agricultura, Santiago, Chile.

Sáenz de Cabezón, F., V. Maron, F. Zalom, and I. Pérez-Moreno. 2005. Effects of methoxyfenozide on Lobesia botrana (Den. \& Schiff.) (Lepidoptera: Torticidae) egg, larval and adult stages. Pest Management Science 61: 1133-1137.

(SENASA) Servicio Nacional de Sanidad y Calidad Agroalimentaria. 2015. El SENASA declaró la emergencia fitosanitaria por la detección de la plaga Lobesia botrana. Fecha de consulta: Septiembre de 2015.

Thiéry, D. 2008. Les Tordeuses nuisibles à la vigne, pp. 214-246. In Les ravageurs de la vigne. Second Edition. Féret, Bordeaux, France.

Torres-Vila, L. M., J. Stockel, R. Roehrich, and M. C. Rodríguez-Molina. 1997. The relation between dispersal and survival of Lobesia botrana larvae and their density in vine inflorescences. Entomologia Experimentalis et Applicata 84: 109-114.

Varela, L. G., R. J. Smith, M. L. Cooper, and R. W. Hoenisch. 2010. European grapevine moth, Lobesia botrana, in Napa Valley vineyards. Practical Winery \& Vineyard. 30: 1-5.

Vassiliou, V. A. 2009. Control of Lobesia botrana (Lepidoptera: Tortricidae) in vineyards in Cyprus using the mating disruption technique. Crop Protection 28: 145-150.

Xuéreb, A, and D. Thiéry. 2006. Does natural larval parasitism of Lobesia botrana (Lepidoptera: Torticidae) vary between years, generation, density of the host and vine cultrivar? Bulletin of Entomological Research 96: 105-110.

Zangheri, S., G. Briolini, P. Cravedi, C. Duso, F. Molinari, and E. Pasqualini. 1992. Lobesia botrana (Denis \& Schiffermüller), pp. 85-88. In Lepidotteri dei fruttiferi e della vite. Milan, Italy. 